\title{
SYNTHESIS AND MAGNETIC PROPERTIES OF BINUCLEAR COMPLEX $\left[\mathrm{N}\left(\mathrm{n}-\mathrm{C}_{4} \mathrm{H}_{9}\right)_{4}\right]\left[\mathrm{Mn}{ }^{\prime \prime} \mathrm{Fe} \mathrm{I}^{\prime \prime \prime}(\mathrm{ox})_{3}\right]$
}

\author{
Fahimah Martak*, Hamzah Fansuri, and Sekarayu Dianing Putri \\ Department of Chemistry, Institut Teknologi Sepuluh Nopember, \\ Kampus ITS Sukolilo Surabaya 60111
}

Received September 7, 2011; Accepted February 10, 2012

\begin{abstract}
Binuclear complex, $\left[\mathrm{N}\left(n-\mathrm{C}_{4} \mathrm{H}_{9}\right)_{4}\right]\left[\mathrm{Mn}^{\prime \prime} \mathrm{Fe}^{\prime \prime \prime}(\mathrm{ox})_{3}\right]$ (ox=oxalate), has been synthesized and characterized. Binuclear complex with formula of $\left[\mathrm{N}\left(n-\mathrm{C}_{4} \mathrm{H}_{9}\right)_{4}\right]\left[\mathrm{Mn}^{\prime \prime} \mathrm{Fe}^{\prime \prime \prime}(\mathrm{ox})_{3}\right]$ was synthesized by forming precursor $\mathrm{K}_{3}\left[\mathrm{Fe}(\mathrm{ox})_{3}\right]$ which was followed by adding manganese chloride and tetrabutyl ammonium chloride. Characterization of the complex was made by microanalysis, FT-IR spectroscopy, $x$-ray diffraction and Magnetic Susceptibility Balance. Magnetic moment of binuclear complex $\left[\mathrm{N}\left(n-\mathrm{C}_{4} \mathrm{H}_{9}\right)_{4}\right]\left[\mathrm{Mn}{ }^{\prime \prime} \mathrm{Fe} \mathrm{e}^{\prime \prime \prime}(\mathrm{ox})_{3}\right]$ is $7.81 \mathrm{BM}$. The compound has higher magnetic moment than the previously reported compound with different organic cation, $\left[N\left(n-C_{5} H_{11}\right)_{4}\right]\left[\mathrm{Mn}^{\prime \prime} \mathrm{Fe}{ }^{\prime \prime \prime}(\mathrm{ox})_{3}\right]$. This behavior might be associated with the decreasing range among layers on polymeric network.
\end{abstract}

Keywords: Binuclear complex; oxalato network; iron complex; magnetic properties; $X$-ray powder diffraction

\section{ABSTRAK}

Kompleks Binuklir, $\left[\mathrm{N}\left(\mathrm{n}-\mathrm{C}_{4} \mathrm{H}_{9}\right)_{4}\right]\left[\mathrm{Mn}^{\prime \prime} \mathrm{Fe}^{\prime \prime \prime}(\mathrm{ox})_{3}\right]$ (ox=oxalate), telah disintesis dan dikarakterisasi. Kompleks binuklir dengan formula, $\left[\mathrm{N}\left(\mathrm{n}-\mathrm{C}_{4} \mathrm{H}_{9}\right)_{4}\right]\left[\mathrm{Mn}^{\prime \prime} \mathrm{Fe}^{\prime \prime \prime}(\mathrm{ox})_{3}\right]$ disintesis melalui pembentukan precursor kristal $\mathrm{K}_{3}\left[\mathrm{Fe}(\mathrm{ox})_{3}\right]$ yang selanjutnya dilakukan penambahan mangan klorida dan tetrabutil ammonium klorida. Padatan hasil sintesis dikarakterisasi dengan analisis unsur, teknik difraksi sinar-X (XRD), spektroskopi FTIR dan Suseptibilitas magnetik balans. Pada penelitian ini diketahui bahwa moment magnetik kompleks binuklir adalah 7,81 BM. Nilai moment magnetik senyawa ini lebih tinggi dari yang dilaporkan sebelumnya dengan kation yang berbeda, $[N(n-$ $\left.\left.\mathrm{C}_{5} \mathrm{H}_{11}\right)_{4}\right]\left[\mathrm{Mn}^{\prime \prime} \mathrm{Fe} \mathrm{e}^{\prime \prime \prime}(\mathrm{ox})_{3}\right]$. Sifat magnetik yang lebih tinggi ini dihubungkan dengan menurunnya jarak antar lapisan pada jejaring polimer.

Kata Kunci: Kompleks binuklir; jejaring oksalat; kompleks besi; sifat magnetik; difraksi sinar-X

\section{INTRODUCTION}

Molecular magnet based on polynuclear complexes has superior magnetic properties than mononuclear complexes. For example, the magnetic moment of $[\mathrm{N}(\mathrm{n}-$ $\left.\left.\mathrm{C}_{5} \mathrm{H}_{11}\right)_{4}\right]\left[\mathrm{Mn}^{\mathrm{II}} \mathrm{Fe}^{\text {III }}(\mathrm{Ox})_{3}\right]$ is $7.5 \mathrm{BM}$ [1], while the magnetic moment of its respective mononuclear complex $\mathrm{K}_{3} \mathrm{Fe}(\mathrm{Ox})_{3}$ is $5.8 \mathrm{BM}$ [2]. Interactions among metal ions in the polynuclear complex improve their total magnetic moment.

The magnetic moment of polynuclear complexes is a function of the size of organic cation. Decreasing the cation size will increase the magnetic moment followed by the increase in temperature of paramagneticantiferomagnetic transition.

Studies on the effect of organic cation size to magnetic moment of polynuclear complexes have been reported. For an example, Mathoriene et al. (1996) reported that binuclear complex $\left[\mathrm{N}\left(\mathrm{n}-\mathrm{C}_{5} \mathrm{H}_{11}\right)_{4}\right]$ $\left[\mathrm{Mn}^{\text {II }} \mathrm{Fe}^{\text {III }}(\mathrm{ox})_{3}\right]$ had paramagnetic-antiferomagnetic transition at $27 \mathrm{~K}$ and effective magnetic moment 7.71 BM. The crystal structure of the complex was investigated later [3].

Tetra-Butylamine $\left[\mathrm{N}\left(\mathrm{n}-\mathrm{C}_{4} \mathrm{H}_{9}\right)_{4}\right]^{+}$is an organic cation which is smaller than tetra-pentylamine, $[\mathrm{N}(\mathrm{n}$ $\left.\left.\mathrm{C}_{5} \mathrm{H}_{11}\right)_{4}\right]^{+}$. Therefore, when the former cation replaces the $\left[\mathrm{N}\left(\mathrm{n}-\mathrm{C}_{5} \mathrm{H}_{11}\right)_{4}\right]$ in $\left[\mathrm{N}\left(\mathrm{n}-\mathrm{C}_{5} \mathrm{H}_{11}\right)_{4}\right]\left[\mathrm{Mn}{ }^{\prime \prime} \mathrm{Fe}{ }^{\prime \prime \prime}(\mathrm{Ox})_{3}\right]$, the magnetic moment of the complex will increase. This paper reports the research results of the substitution and its effect on the complex magnetic moment. The polyanion complex was synthesized from $\mathrm{K}_{3} \mathrm{Fe}(\mathrm{Ox})_{3}$ precursor.

\section{EXPERIMENTAL SECTION}

\section{Materials}

All chemicals were reagent grade and were used as commercially obtained, such as $\mathrm{MnCl}_{2} \cdot 4 \mathrm{H}_{2} \mathrm{O}$, $\left[\left(\mathrm{NH}_{4}\right)_{2} \mathrm{Fe}\left(\mathrm{H}_{2} \mathrm{O}\right)_{2}\left(\mathrm{SO}_{4}\right)_{2}\right] \cdot 4 \mathrm{H}_{2} \mathrm{O}, \mathrm{H}_{2} \mathrm{SO}_{4} 6 \mathrm{M}$, methanol,

* Corresponding author. Tel/Fax : +62-81572535690

Email address : fahimahm@chem.its.ac.id 


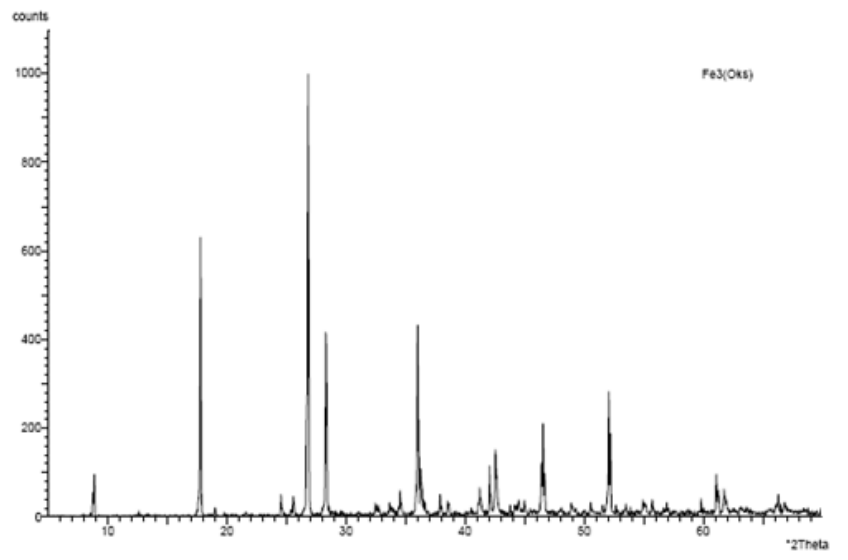

Fig 1. X-Ray difraction of $\mathrm{K}_{3}\left[\mathrm{Fe}(\mathrm{ox})_{3}\right] \cdot 3 \mathrm{H}_{2} \mathrm{O}$

Table 1. Comparison of characteristic peaks $\mathrm{K}_{3}\left[\mathrm{Fe}(\mathrm{ox})_{3}\right] \cdot 3 \mathrm{H}_{2} \mathrm{O}$ which was synthesized and matched to standard reference of $\left[\mathrm{Fe}\left(\mathrm{C}_{2} \mathrm{O}_{4}\right)_{3}\right]^{3-}$

\begin{tabular}{cc}
\hline \multicolumn{2}{c}{$2 \theta$} \\
\hline $\begin{array}{c}\mathrm{K}_{3}\left[\mathrm{Fe}(\mathrm{ox})_{3}\right]_{3} \mathrm{H}_{2} \mathrm{O} \\
\text { which was synthesized }\end{array}$ & $\begin{array}{c}\text { Standart reference of } \\
{\left[\mathrm{Fe}\left(\mathrm{C}_{2} \mathrm{O}_{4}\right)_{3}\right]^{3-}}\end{array}$ \\
\hline 17.78 & 19.81 \\
26.83 & 26.17 \\
28.33 & 28.06 \\
36.02 & 36.58 \\
42.57 & 43.77 \\
52.06 & 55.23 \\
61.1 & 61.29 \\
\hline
\end{tabular}

$\mathrm{H}_{2} \mathrm{C}_{2} \mathrm{O}_{4} \cdot 2 \mathrm{H}_{2} \mathrm{O}, \mathrm{K}_{2} \mathrm{C}_{2} \mathrm{O}_{4} \cdot \mathrm{H}_{2} \mathrm{O}, \mathrm{H}_{2} \mathrm{O}_{2}$, tetra-butyl ammonium chloride and aquadest.

\section{Instrumentation}

Metal content was determined by Absorption Atomic Spectroscopy Shimadzu AA8801S. Elemental analyses $(\mathrm{C}, \mathrm{H}, \mathrm{N})$ were performed on Fison EA 1108 microanalytical analyzer at Universiti Kebangsaan Malaysia. The FT-IR spectra was recorded on Shimadzu FTIR-8400 spectrometer in the $4000-400 \mathrm{~cm}^{-1}$ spectral regions and Absorption Atomic Spectroscopy at Institut Teknologi Sepuluh Nopember, Powder X-ray diffraction measurements was performed Philip X'Pert PN-1830 XRay, at Research Center Institut Teknologi Sepuluh Nopember while magnetic susceptibility was measured by Magway MSB from Sherwood Scientific LTD at Universitas Airlangga.

\section{Procedure}

\section{Synthesis Complex $\mathrm{K}_{3}\left[\mathrm{Fe}(\mathrm{ox})_{3}\right] \cdot 3 \mathrm{H}_{2} \mathrm{O}$}

$10.06 \mathrm{~g}$ ammonium ferrous sulphate hexahydrate was dissolved in $30 \mathrm{~mL}$ of hot water and acidified with dilute sulphuric acid. A hot solution of $6.36 \mathrm{~g}$ of oxalic acid dihydrate in $50 \mathrm{~mL}$ of aquadest was added.

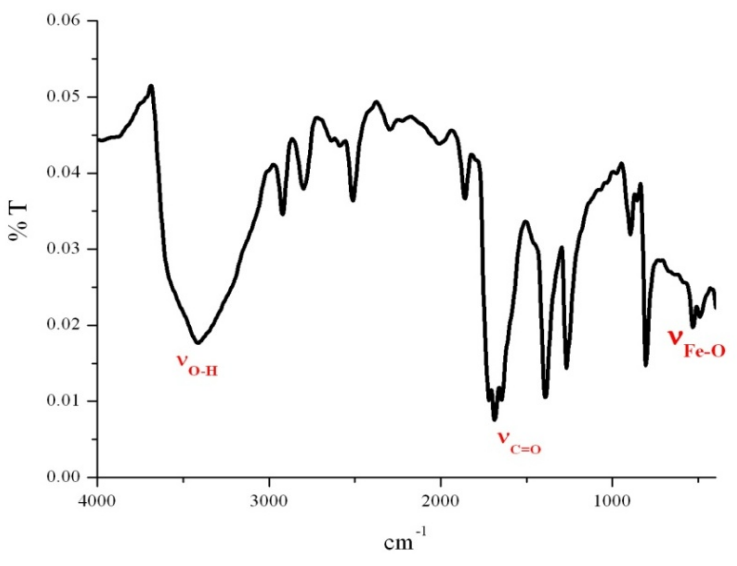

Fig 2. The spectrum of $\mathrm{K}_{3}\left[\mathrm{Fe}(\mathrm{ox})_{3}\right] \cdot 3 \mathrm{H}_{2} \mathrm{O}$

Cautiously the mixture was heated to boiling and then allowed the yellow precipitate of iron(II) oxalate, $\mathrm{FeC}_{2} \mathrm{O}_{4} \cdot 2 \mathrm{H}_{2} \mathrm{O}$, to settle. The precipitate was washed with $30 \mathrm{~mL}$ water by decantation. A warm solution of $6.62 \mathrm{~g}$ potassium oxalate monohydrate in $18 \mathrm{~mL}$ of aquadest was added. $10 \mathrm{~mL}$ hydrogen peroxide was added, the solution was stirred continuously and the temperature was kept below $40{ }^{\circ} \mathrm{C}$. Then the mixture was heated, the brown precipitate was formed. Saturated solution of $1.62 \mathrm{~g}$ oxalic acid dihydrate in $13 \mathrm{~mL}$ of aquadest was added until the precipitate just redisolved. The solution was filtered, and then $20 \mathrm{~mL}$ of methanol was added. It was left to crystallize in the dark. When the green crystal of the complex has appeared, the solution filtered and the crystals were washed in ethanol, then with acetone. The crystals were allowed to dry at room temperature in the dark. The product was stored in glass specimen tube and wrapped in aluminium foil [4].

\section{Synthesis Complex Binuclear $\left[\mathrm{N}\left(\mathrm{n}-\mathrm{C}_{4} \mathrm{H}_{9}\right)_{4}\right][\mathrm{Mn}$ $\left.\mathrm{Fe}(\mathrm{ox})_{3}\right]$}

An aqueous solution of $0.34 \mathrm{~g} \mathrm{MnCl}_{2} .4 \mathrm{H}_{2} \mathrm{O}$ in $10 \mathrm{~mL}$ of aquadest was added dropwise to an aqueous solution $0.99 \mathrm{~g}$ of $\mathrm{K}_{3}\left[\mathrm{Fe}(\mathrm{ox})_{3}\right] \cdot 3 \mathrm{H}_{2} \mathrm{O}$ in $10 \mathrm{~mL}$ aquadest at room temperature. The solution was evaporated at ambient temperature for $1 \mathrm{~h}$. An aqueous of tetrabutyl ammonium chloride was then slowly added to the solution during stirring. After approximately $12 \mathrm{~h}$, the product was collected by filtration, washed with $\mathrm{H}_{2} \mathrm{O}$ and $\mathrm{EtOH}$, and dried in vacuo [5].

\section{RESULT AND DISCUSSION}

\section{Complex $\mathrm{K}_{3}\left[\mathrm{Fe}(\mathrm{ox})_{3}\right] \cdot 3 \mathrm{H}_{2} \mathrm{O}$}

This complex is synthesized on two phases. The first phase is a synthesis of $\mathrm{Fe}(\mathrm{II})$ oxalate complex. The second phase is a forming of green crystalline 
Table 2. The metal ion and $\mathrm{C}, \mathrm{H}$ and $\mathrm{N}$ contents of binuclear complex

\begin{tabular}{lccccc}
\hline $\begin{array}{c}\text { Compound } \\
{\left[\mathrm{N}\left(\mathrm{n}-\mathrm{C}_{4} \mathrm{H}_{9}\right)_{4}\right]\left[\mathrm{Mn}^{\text {II }} \mathrm{Fe}{ }^{\text {III }}(\mathrm{ox})_{3}\right]}\end{array}$ & $\mathrm{Mn}$ & $\mathrm{Fe}$ & $\mathrm{C}$ & $\mathrm{H}$ & $\mathrm{N}$ \\
\hline & 8.77 & 8.61 & 42.97 & 5.66 & 2.35 \\
& $8.91^{*}$ & $9.08^{*}$ & $42.79^{*}$ & $5.83^{*}$ & $2.69^{*}$ \\
\hline${ }^{*}$ Calculated
\end{tabular}

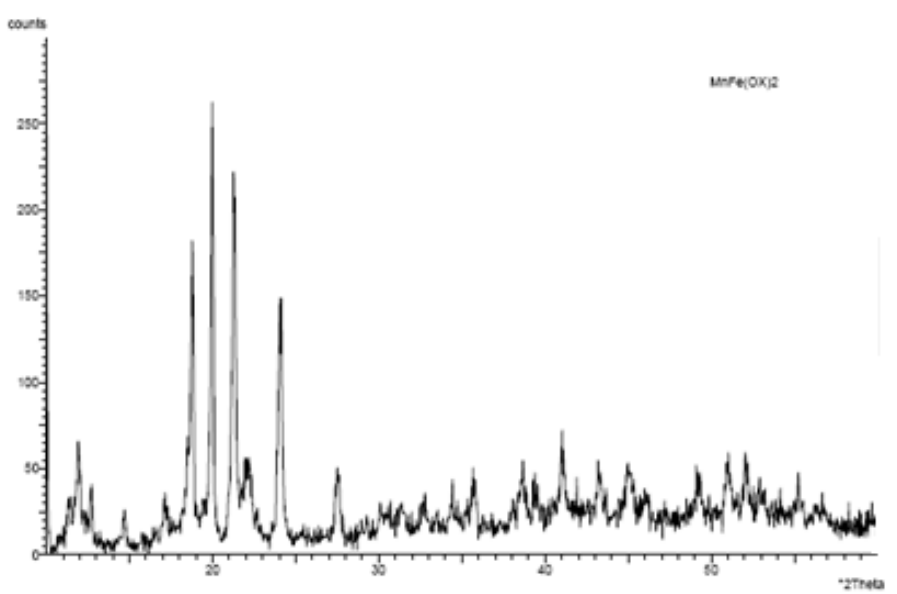

Fig 3. X-Ray Difraction of $\left[\mathrm{N}\left(\mathrm{n}-\mathrm{C}_{4} \mathrm{H}_{9}\right)_{4}\right]\left[\mathrm{Mn}{ }^{\prime \prime} \mathrm{Fe}{ }^{\text {III }}(\mathrm{ox})_{3}\right]$

Table 3. The characteristic peaks of $[N(n-$ $\frac{\left.\left.\mathrm{C}_{4} \mathrm{H}_{9}\right)_{4}\right]\left[\mathrm{Mn}^{\text {II }} \mathrm{Fe}^{\mathrm{III}}(\mathrm{ox})_{3}\right] \text { and }\left[\mathrm{N}\left(\mathrm{n}-\mathrm{C}_{5} \mathrm{H}_{11}\right)_{4}\right]\left[\mathrm{Mn}^{\mathrm{II}} \mathrm{Fe} \mathrm{e}^{\mathrm{III}}(\mathrm{ox})_{3}\right]}{2 \theta}$

\begin{tabular}{|c|c|}
\hline $\begin{array}{c}\text { Binuclear Complex } \\
{\left[\mathrm{N}\left(\mathrm{nC}_{4} \mathrm{H}_{9}\right)_{4}\right]\left[\mathrm{Mn}^{\text {II }} \mathrm{Fe}^{\text {III }}(\mathrm{ox})_{3}\right]}\end{array}$ & $\begin{array}{c}\text { Binuclear Complex } \\
{\left[\mathrm{N}\left(\mathrm{nC}_{5} \mathrm{H}_{11}\right)_{4}\right]\left[\mathrm{Mn}^{\prime \prime} \mathrm{Fe} \mathrm{e}^{\mathrm{III}}(\mathrm{ox})_{3}\right]}\end{array}$ \\
\hline 11.97 & $11.89 ; 12.23$ \\
\hline- & $12.98 ; 13.01$ \\
\hline $14.71 ; 17.13$ & $14.79 ; 16.86$ \\
\hline $18.8 ; 19.99$ & $18.43 ; 19.51$ \\
\hline $21.30 ; 22.13$ & $21.07 ; 22.08$ \\
\hline 24.09 & 23.95 \\
\hline
\end{tabular}

\section{$\mathrm{K}_{3}\left[\mathrm{Fe}(\mathrm{ox})_{3}\right] \cdot 3 \mathrm{H}_{2} \mathrm{O}$ complex.}

The reaction of the process is represented as follows:

$\left(\mathrm{NH}_{4}\right)_{2}\left[\mathrm{Fe}\left(\mathrm{H}_{2} \mathrm{O}\right)_{2}\left(\mathrm{SO}_{4}\right)_{2}\right] \cdot 4 \mathrm{H}_{2} \mathrm{O}+\mathrm{H}_{2} \mathrm{C}_{2} \mathrm{O}_{4} \cdot 2 \mathrm{H}_{2} \mathrm{O} \rightarrow \mathrm{FeCC}_{2} \mathrm{O}_{4}+\mathrm{H}_{2} \mathrm{SO}_{4}+\left(\mathrm{NH}_{4}\right)_{2} \mathrm{SO}_{4}+8 \mathrm{H}_{2} \mathrm{O}$ $\mathrm{H}_{2} \mathrm{C}_{2} \mathrm{O}_{4} \cdot 2 \mathrm{H}_{2} \mathrm{O}+2 \mathrm{FeC}_{2} \mathrm{O}_{4}+3 \mathrm{~K}_{2} \mathrm{C}_{2} \mathrm{O}_{4} \cdot \mathrm{H}_{2} \mathrm{O}+\mathrm{H}_{2} \mathrm{O}_{2} \rightarrow 2 \mathrm{~K} 3[\mathrm{Fe}(\mathrm{Ox}) 3]_{3} \cdot 3 \mathrm{H}_{2} \mathrm{O}+\mathrm{H}_{2} \mathrm{O}$

The $\mathrm{K}_{3}\left[\mathrm{Fe}(\mathrm{ox})_{3}\right] \cdot 3 \mathrm{H}_{2} \mathrm{O}$ complex was used as precursor to get binuclear complex $\left[\mathrm{N}\left(\mathrm{n}-\mathrm{C}_{4} \mathrm{H}_{9}\right)_{4}\right]$ $\left[\mathrm{Mn}^{\text {II }} \mathrm{Fe}^{\text {III }}(\mathrm{ox})_{3}\right]$. However, the binuclear complex was further characterized by X-Ray Powder Diffraction. It is listed in Fig. 1.

The Diffractogram of $\mathrm{K}_{3}\left[\mathrm{Fe}(\mathrm{ox})_{3}\right] \cdot 3 \mathrm{H}_{2} \mathrm{O}$ has similar pattern to iron(III) oxalate's diffraction on 14-0807 International Centre for Diffraction Data Reference. The characteristic peaks of $\mathrm{K}_{3}\left[\mathrm{Fe}(\mathrm{ox})_{3}\right] \cdot 3 \mathrm{H}_{2} \mathrm{O}$ which were synthesized and matched to standard reference of $\left[\mathrm{Fe}\left(\mathrm{C}_{2} \mathrm{O}_{4}\right)_{3}\right]^{3-}$ is listed Table 1.

The formula of the compound is also supported by infrared spectrum. The absorption peak at $3560 \mathrm{~cm}^{-1}$ indicated by a stretching vibration of $\mathrm{OH}$ [6], Stretching vibration $\mathrm{C}=\mathrm{O}$ from free oxalate ligand is shown at
$1688 \mathrm{~cm}^{-1}$, and for $v(\mathrm{Fe}-\mathrm{O})$ bands at $472 \mathrm{~cm}^{-1}$ [7]. The spectrum of the complex is shown in Fig. 2 .

The absorption peak at $3688.02 \mathrm{~cm}^{-1}$ is indicated by a stretching vibration of $\mathrm{OH}$. Stretching vibration $\mathrm{C}=\mathrm{O}$ from oxalate is showed at $1658.84 \mathrm{~cm}^{-1}$. Stretching vibration Fe-O has been observed at 459.07 $\mathrm{cm}^{-1}$. This spectrum is similar to spectrum which was reported [6]. It is indicated that $\mathrm{K}_{3}\left[\mathrm{Fe}(\mathrm{ox})_{3}\right] \cdot 3 \mathrm{H}_{2} \mathrm{O}$ has formed.

\section{Binuclear Complex $\left[\mathrm{N}\left(\mathrm{n}-\mathrm{C}_{4} \mathrm{H}_{9}\right)_{4}\right]\left[\mathrm{Mn}{ }^{\prime \prime} \mathrm{Fe}{ }^{\prime \prime \prime}(\mathrm{ox})_{3}\right]$}

Binuclear complex $\left[\mathrm{N}\left(\mathrm{n}-\mathrm{C}_{4} \mathrm{H}_{9}\right)_{4}\right]\left[\mathrm{Mn}^{\text {II }} \mathrm{Fe}^{\text {III }}(\mathrm{ox})_{3}\right]$ was synthesized by forming precursor $\mathrm{K}_{3}\left[\mathrm{Fe}(\mathrm{ox})_{3}\right]$ which was followed by adding manganese chloride and tetrabutyl ammonium $\left[\mathrm{N}\left(\mathrm{n}-\mathrm{C}_{4} \mathrm{H}_{9}\right)_{4}\right]^{+}$, solvened by aquadest as solvent. Yellow crystalline binuclear complex $\left[\mathrm{N}\left(\mathrm{n}-\mathrm{C}_{4} \mathrm{H}_{9}\right)_{4}\right]\left[\mathrm{Mn}{ }^{\text {II }} \mathrm{Fe} \mathrm{e}^{\text {III }}(\mathrm{ox})_{3}\right]$ was resulted from this reaction. follows:

The reaction of the process is represented as

$2 \mathrm{~K}_{3}\left[\mathrm{Fe}(\mathrm{ox})_{3}\right] \cdot 3 \mathrm{H}_{2} \mathrm{O}+2 \mathrm{MnCl}_{2} \cdot 4 \mathrm{H}_{2} \mathrm{O}+2\left[\left(\mathrm{~N}\left(\mathrm{n}-\mathrm{C}_{4} \mathrm{H}_{9}\right)_{4} \mathrm{Cl}\right] \longrightarrow\right.$ $2\left\{\left[\left(\mathrm{~N}\left(\mathrm{n}-\mathrm{C}_{4} \mathrm{H}_{9}\right) 4\right][\mathrm{MnFe}(\mathrm{ox}) 3]\right\}+6 \mathrm{KCl}+7 \mathrm{H}_{2} \mathrm{O}\right.$

The formula of the complex resulted from elemental content is listed in Table 2. This table shows that the content of binuclear complex experiment suitable to the calculated content of binuclear complex $\left[\mathrm{N}\left(\mathrm{n}-\mathrm{C}_{4} \mathrm{H}_{9}\right)_{4}\right]\left[\mathrm{Mn}^{\mathrm{II}} \mathrm{Fe}^{\mathrm{III}}(\mathrm{ox})_{3}\right]$.

This complex was further characterized by X-Ray Powder Diffraction. They are listed in Fig. 3.

The diffraction pattern of the complex was suitable to binuclear complex $\left[\mathrm{N}\left(\mathrm{n}-\mathrm{C}_{5} \mathrm{H}_{11}\right)_{4}\right]$ $\left[\mathrm{Mn}^{\text {II }} \mathrm{Fe}^{\text {III }}(\mathrm{ox})_{3}\right.$ ] which was reported [9]. The peaks of these diffraction complexes, (20) 12.23; 12.98 and $13.01^{\circ}$ have different areas with binuclear complex $\left[\mathrm{N}\left(\mathrm{n}-\mathrm{C}_{5} \mathrm{H}_{11}\right)_{4}\right]\left[\mathrm{Mn}{ }^{\text {II }} \mathrm{Fe}^{\text {III }}(\mathrm{ox})_{3}\right]$. It is caused by different cation organic on complex binuclear $\left[\mathrm{Mn}^{\text {II }} \mathrm{Fe}^{\prime \prime \prime}(\mathrm{ox})_{3}\right]$, so it influences the distance of interlayers on polymeric network. The characteristic peaks of $\left[\mathrm{N}\left(\mathrm{n}-\mathrm{C}_{4} \mathrm{H}_{9}\right)_{4}\right]$ $\left[\mathrm{Mn}^{\text {II }} \mathrm{Fe}^{\text {III }}(\mathrm{ox})_{3}\right]$ and $\left[\mathrm{N}\left(\mathrm{n}-\mathrm{C}_{5} \mathrm{H}_{11}\right)_{4}\right]\left[\mathrm{Mn}^{\mathrm{II}} \mathrm{Fe}^{\text {III }}(\mathrm{ox})_{3}\right]$, are listed in Table 3.

These similar characteristic peaks of binuclear complex $\left.\left[\mathrm{N}\left(\mathrm{n}-\mathrm{C}_{4} \mathrm{H}_{9}\right)_{4}\right]\left[\mathrm{Mn}{ }^{\prime \prime} \mathrm{Fe} \mathrm{e}^{\text {III }}(\mathrm{ox})_{3}\right]\right\}$ and $\left[\mathrm{N}\left(\mathrm{n}-\mathrm{C}_{5} \mathrm{H}_{11}\right)_{4}\right]$ $\left.\left[\mathrm{Mn}^{\text {"IFe }} \mathrm{Fe}^{\mathrm{III}}(\mathrm{Ox})_{3}\right]\right\}$ indicated that both of their interlayer structures are similar too. So, it means that the space group of binuclear complex $\left.\left[\mathrm{N}\left(\mathrm{n}-\mathrm{C}_{4} \mathrm{H}_{9}\right)_{4}\right]\left[\mathrm{Mn}{ }^{\text {II }} \mathrm{Fe}{ }^{\text {III }}(\mathrm{ox})_{3}\right]\right\}$ is $P 6(3)$ and it comprises two layers which was reported [9]. 
Table 4. Infrared spectrum of binuclear complex $\left[\mathrm{N}\left(\mathrm{n}-\mathrm{C}_{4} \mathrm{H}_{9}\right)_{4}\right]\left[\mathrm{Mn}{ }^{\prime \prime} \mathrm{Fe}\right.$ "II $\left.(\mathrm{ox})_{3}\right]$

\begin{tabular}{cc}
\hline Function Group & $\begin{array}{c}\text { Absorbtion Areas } \\
\left(\mathbf{c m}^{-1}\right)\end{array}$ \\
\hline $\mathrm{v}_{\mathrm{C}=\mathrm{O}}$ Oxalate as bridge ligand & 1627.97 \\
& 1346.36 \\
& 898.86 \\
$\mathrm{~V}_{\mathrm{C}=\mathrm{H}}$ butyl which was bonding to ammonium & 2970.48 \\
& 1446.66 \\
$\mathrm{Mn}-\mathrm{O}$ & 408.92 \\
$\mathrm{Fe}-\mathrm{O}$ & 486.08 \\
\hline
\end{tabular}

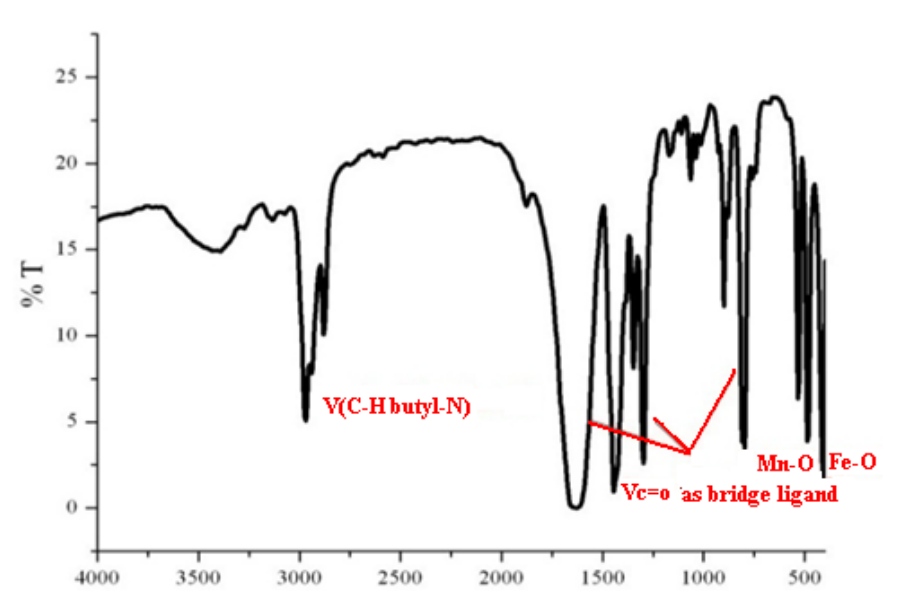

Fig 4. Spectrum of $\left[\mathrm{N}\left(\mathrm{n}^{-1}-\mathrm{C}_{4} \mathrm{H}_{9}\right)_{4}\right]\left[\mathrm{Mn}^{\mathrm{II}} \mathrm{Fe} \mathrm{e}^{\mathrm{III}}(\mathrm{ox})_{3}\right]$

The complex was analyzed by infrared spectrum to support the formula. The spectrum of the function group to support the formula was reported. Stretching vibration $\mathrm{C}=\mathrm{O}$ indicated oxalate as bridge ligand at 1627, 1330 and $800 \mathrm{~cm}^{-1}$ [10-11]. Stretching and bending vibration $\mathrm{C}-\mathrm{H}$ aliphatic from tetra butyl was been observed at 2936.6 and $1432 \mathrm{~cm}^{-1}$. The bands at frequency 472.7 and $410.9 \mathrm{~cm}^{-1}$ indicated bond between $\mathrm{Fe}-\mathrm{O}$ and $\mathrm{Mn}-\mathrm{O}$ [12]. The spectrum of the complex is shown in Fig. 4.

The analysis of infrared spectrum can indicate the function group of binuclear complex $\left[\mathrm{N}\left(\mathrm{n}-\mathrm{C}_{4} \mathrm{H}_{9}\right)_{4}\right]$ [Mn $\left.{ }^{\prime \prime} \mathrm{Fe}^{\prime \prime \prime}(\mathrm{ox})_{3}\right]$, which is listed is Table 4.

The absorption at $2970.48 \mathrm{~cm}^{-1}$ indicates stretching vibration of $\mathrm{C}-\mathrm{H}$ butyl which was bonding to ammonium. At the same time, $v(\mathrm{CO})$ stretching at $1627.97 ; 1346.36$; and $898.86 \mathrm{~cm}^{-1}$ shifted to lower frequency suggests that oxalate as bridge ligand. Another band appeared in spectra of the complex at 408.92 and $486.08 \mathrm{~cm}^{-1}$ is due to stretching vibration $\mathrm{Mn}-\mathrm{O}$ and $\mathrm{Fe}-\mathrm{O}$.

The further analysis of binuclear complex $[\mathrm{N}(\mathrm{n}-$ $\left.\left.\mathrm{C}_{4} \mathrm{H}_{9}\right)_{4}\right]\left[\mathrm{Mn}^{\prime \prime} \mathrm{Fe}^{\prime \prime \prime}(\mathrm{ox})_{3}\right]$ which was a synthesis showed similar result to binuclear complex $\left[\mathrm{N}\left(\mathrm{n}-\mathrm{C}_{5} \mathrm{H}_{11}\right)_{4}\right]\left[\mathrm{Mn}^{\prime \prime}\right.$ $\mathrm{Fe}^{\text {III }}(\mathrm{ox})_{3}$ ] was reported previously, so we can infer that the complex has been formed The similar characteristic of both $\left[\mathrm{N}\left(\mathrm{n}-\mathrm{C}_{5} \mathrm{H}_{11}\right)_{4}\right]\left[\mathrm{Mn}{ }^{\prime \prime} \mathrm{Fe}{ }^{\prime \prime \prime}(\mathrm{ox})_{3}\right]$ and $\left[\mathrm{N}\left(\mathrm{n}-\mathrm{C}_{4} \mathrm{H}_{9}\right)_{4}\right]$ $\left[\mathrm{Mn}^{\prime \prime} \mathrm{Fe}^{\prime \prime \prime}(\mathrm{ox})_{3}\right]$ suggests that their structures are similar too.

\section{Magnetic Properties of complex $\left[\mathrm{N}\left(\mathrm{n}-\mathrm{C}_{4} \mathrm{H}_{9}\right)_{4}\right]\left[\mathrm{Mn}{ }^{\prime \prime}\right.$ $\left.\mathrm{Fe}^{\mathrm{III}}(\mathrm{ox})_{3}\right]$}

Magnetism of the bimetallic tris-oxalato $[\mathrm{N}(\mathrm{n}$ $\left.\left.\mathrm{C}_{4} \mathrm{H}_{9}\right)_{4}\right]\left[\mathrm{Mn}{ }^{\prime \prime} \mathrm{Fe}^{\prime \prime \prime}(\mathrm{ox})_{3}\right]$ can be observed by analyzing the moment of magnetic value by Magnetic Susceptibility Balances.

The value of moment magnetic complex was measured at $7.81 \mathrm{BM}$. This value having higher value than binuclear complex $\left[\mathrm{P}\left(\mathrm{n}-\mathrm{C}_{5} \mathrm{H}_{11}\right)_{4}\right]\left[\mathrm{Mn}^{\mathrm{N}} \mathrm{Fe} \mathrm{F}^{\mathrm{II}}(\mathrm{ox})_{3}\right]$ was reported [13] giving value of $7.71 \mathrm{BM}$. This proves that decreasing range among layers on polymeric network by substituting organic cation $\left[\mathrm{P}\left(\mathrm{n}-\mathrm{C}_{5} \mathrm{H}_{11}\right)_{4}\right]^{+}$with $[\mathrm{N}(\mathrm{n}-$ $\left.\left.\mathrm{C}_{4} \mathrm{H}_{9}\right)_{4}\right]^{+}$can increase compound magnetic interaction.

The calculated magnetic moment related to the spin of metal ion. In this case, $\mathrm{Mn}^{11}$ and $\mathrm{Fe}^{\mathrm{III}}$ give a number of spins which is calculated as follows $\mathrm{S}_{\mathrm{T}}=\mathrm{S}_{\mathrm{Fe}}+\mathrm{S}_{\mathrm{Mn}} \quad\left(\mathrm{S}_{\mathrm{Fe}}=5 / 2 ; \quad \mathrm{S}_{\mathrm{Mn}}=5 / 2\right) . \quad$ The produced binuclear complex $\left[\mathrm{N}\left(\mathrm{n}-\mathrm{C}_{4} \mathrm{H}_{9}\right)_{4}\right]\left[\mathrm{Mn}{ }^{\prime \prime} \mathrm{Fe} \mathrm{e}^{\prime \prime \prime}(\mathrm{ox})_{3}\right.$ is high spin. This indicates that binuclear complex $\left[\mathrm{N}\left(\mathrm{n}-\mathrm{C}_{4} \mathrm{H}_{9}\right)_{4}\right]$ $\left[\mathrm{Mn}^{\mathrm{II}} \mathrm{Fe}^{\text {III }}(\mathrm{ox})_{3}\right.$ is paramagnetic.

It was reported [13] that complex with $\left[\mathrm{MnFe}(\mathrm{ox})_{3}\right]^{-}$anionic gave antiferomagnetic interaction. The magnetic moment calculated for this interaction was represented as $\mu=g\left(S_{T}\left(S_{T}-1\right)^{1 / 2} \quad(g=2.00023)\right.$. This equation gives effective moment of $\left[\mathrm{N}\left(\mathrm{n}-\mathrm{C}_{4} \mathrm{H}_{9}\right)_{4}\right]$ $\left[\mathrm{MnFe}(\mathrm{ox})_{3}\right]$ at $8.94 \mathrm{BM}$.

The magnetic moment of bimetallic tris-oxalato with $\left[\mathrm{Mn}^{\prime \prime} \mathrm{Fe}^{\prime \prime \prime}(\mathrm{ox})_{3}\right]^{-}$anionic and organic cation, $[\mathrm{N}(\mathrm{n}$ $\left.\left.\mathrm{C}_{4} \mathrm{H}_{9}\right)_{4}\right]^{+}$or $\left[\mathrm{N}\left(\mathrm{n}-\mathrm{C}_{5} \mathrm{H}_{11}\right)_{4}\right]^{+}$was reported [13] giving lower value than the magnetic moment calculated. It caused $\left[\mathrm{MnFe}(\mathrm{ox})_{3}\right]^{-}$anionic having different metal ions but the same spin, $S_{\mathrm{Mn}}=\mathrm{S}_{\mathrm{Fe}}=5 / 2$. This gives alternative nonchollinear chirality, so it makes spin canting and gives different value of gyromagnetic $(\mathrm{g})$ value, which influences the magnetic moment calculated [14].

\section{CONCLUSION}

The analyzed infrared, X-Ray Diffraction and microanalysis conclude that the binuclear complex $\left[\mathrm{N}\left(\mathrm{n}-\mathrm{C}_{4} \mathrm{H}_{9}\right)_{4}\right]\left[\mathrm{Mn} \mathrm{Fe}^{\prime \prime}(\mathrm{ox})_{3}\right]$ has been formed. These complex was synthesized by forming precursor $\mathrm{K}_{3}\left[\mathrm{Fe}(\mathrm{ox})_{3}\right]$ which is followed by adding manganese chloride and tetrabuthylammonium. The value of 
magnetic moment complex was measured at $7.81 \mathrm{BM}$. This value having higher value than binuclear complex $\left[\mathrm{N}\left(\mathrm{n}-\mathrm{C}_{5} \mathrm{H}_{11}\right)_{4}\right]\left[\mathrm{Mn}{ }^{\prime \prime} \mathrm{Fe}{ }^{\prime \prime \prime}(\mathrm{ox})_{3}\right]$ was reported [12] which gives value $7.71 \mathrm{BM}$. This thing proves that decreasing range among layers on polymeric network with substituting organic cation $\left[\mathrm{N}\left(\mathrm{n}-\mathrm{C}_{5} \mathrm{H}_{11}\right)_{4}\right]^{+}$with $[\mathrm{N}(\mathrm{n}-$ $\left.\left.\mathrm{C}_{4} \mathrm{H}_{9}\right)_{4}\right]^{+}$can increase compound magnetic interaction. Binuclear complex $\left[\mathrm{N}\left(\mathrm{n}_{-} \mathrm{C}_{4} \mathrm{H}_{9}\right)_{4}\right]\left[\mathrm{Mn}{ }^{\prime \prime} \mathrm{Fe}{ }^{\prime \prime \prime}(\mathrm{ox})_{3}\right.$ which is produced is high spin. This indicates that binuclear complex $\left[\mathrm{N}\left(\mathrm{n}-\mathrm{C}_{4} \mathrm{H}_{9}\right)_{4}\right]\left[\mathrm{Mn}{ }^{\text {II }} \mathrm{Fe} \mathrm{e}^{\text {III }}(\mathrm{ox})_{3}\right.$ is paramagnetic.

\section{ACKNOWLEDGEMENT}

Authors thank for financial support from Hibah Penelitian PHKI Tema B, Research Grant No. 06960/I2.38/LL/2009, as well as Program Studi Kimia Institut Teknologi Sepuluh Nopember, Universitas Airlangga, Universiti Kebangsaan Malaysia for providing facilities and support to the success of the study.

\section{REFERENCES}

1. Thomas, A.M., Neelakanta, G., Mahadevan, S., Nethaji, M., and Chakravarty, A.R., 2002, J. Inorg. Chem., 2002, 10, 2720-2726.

2. Basolo, F., and Johnson, R.C., 1964, Coordination Chemistry, The Chemistry of Metal Complexes, W.A Benjamin Inc, California.

3. Nuttall, C.J., and Peter D., 1999, J. Solid State Chem., 147, 3-10.

4. Mathoniere, C., Nutall, C.J., Carling, S.G., and Day, P., 1996, Inorg. Chem., 35, 5, 1201-1206
5. Coronado, E., Galán-Mascarós, J.R., Gómez Garzia, C.J., Martinez-Agudo, J.M., MartinezFerrero, E., Waerenborgh, J.C., and Almeida, M., 2001, J. Solid State Chem., 159, 2, 391-402.

6. Edwards, H.G.M., and Russell N.C., 1998, J. Mol. Struct., 443, 1-3, 223-231.

7. Nakamoto, K., 1997, Infrared and Raman Spectra of Inorganic and Coordination Compounds, $5^{\text {th }}$ ed., John Willey and Sons., Inc., New York

8. Andres, R., Brissard, M., Gruselle, M., Train, C., Vaissermann, J., Malézieux, B., Jamet, J-P., and Verdaguer, M., 2001, Inorg. Chem., 40, 18, 46334640.

9. Triki, S., Bérézovsky, F., Pala, J.S., Coronado E., Gomez-Garcia, C.J., Clemente, J.M., Riou, A., and Molinie P., 2000, Inorg. Chem., 39, 17, 3771-3776.

10. Feyerherm R., Loose, A. Lawandy, M.A., and Li, J., 2002, J. Phys. Chem. Solids, 63, 1, 71-73.

11. Martak, F., Onggo, D., Ismunandar, Nugroho, A.A., and Yamin, B.M., 2009, Curr. Res. Chem., 1, 1, 17.

12. Coronado, E. Galán-Mascarós, J.R., Gimenez-Saiz C., Gómez Garzia, C.J., Martinez-Agudo, J.M., and Martinez-Ferrero, E., 2003, Polyhedron, 22, 23812386.

13. Ovanesyan, N.S., Shilov, G.V., Pyalling, A.A., Train, C., Gredin, P., Gruselle, M., Kiss, L.F., and Bottyan, L., 2004, J. Magn. Magn. Mater., 272-276, Part 2, 1089-1090.

14. Real, J.A., Gaspar, A.B., Virginie N., and Munoz, M.C., 2003, Coord. Chem. Rev., 236, 1-2, 121141. 